\title{
Dyspareunia in postmenopausal women: A critical review
}

\author{
Alina Kao PhD Candidate ${ }^{1}$, Yitzchak M Binik $\mathrm{PhD}^{1,2}$, Anita Kapuscinski BA ${ }^{1}$, Samir Khalifé MD 3
}

\author{
A Kao, YM Binik, A Kapuscinski, S Khalifé. Dyspareunia in \\ postmenopausal women: A critical review. Pain Res Manage \\ 2008;13(3):243-254.
}

BACKGROUND: Dyspareunia, or pain during sexual intercourse, is among the problems most frequently reported by postmenopausal women. Past literature has almost unanimously attributed dyspareunic pain occurring during or after the menopausal transition to declining estrogen levels and vaginal atrophy.

OBJECTIVES: To critically review the literature on the prevalence, risk factors, etiology, clinical presentation and treatment of postmenopausal dyspareunia. The present review also examines the traditional and widely held conceptualization of postmenopausal dyspareunia as a direct symptom of hormonal decline.

METHODS: Searches of medical and psychological databases were performed for relevant articles and empirical studies. The methodological quality and outcomes of the studies were systematically reviewed. RESULTS: Available empirical evidence suggests that dyspareunia is common in postmenopausal women, and that it is not highly correlated with menopausal status, estrogen levels or vaginal atrophy. Decreasing levels of endogenous estrogen contribute to the development of dyspareunia in postmenopausal women suffering from vaginal atrophy. Hormonal supplementation is beneficial in alleviating their pain. However, a substantial proportion of treated women do not report relief. CONCLUSIONS: Postmenopausal dyspareunia occurring concurrently with vaginal atrophy is strongly associated with a lack of estrogen in the genital tract. However, a significant percentage of postmenopausal women experience dyspareunic pain that is not caused by hypoestrogenism. It is likely that other types of dyspareunia that occur premenopausally are also occurring in postmenopausal women. Research is needed to adequately address this issue. A change in perspective toward a multiaxial pain-focused approach is proposed for future research concerning dyspareunia in postmenopausal women.

Key Words: Dyspareunia; Estrogen; Hormone replacement therapy; Menopause; Pain; Postmenopausal women; Sexual

$\mathrm{D}$ yspareunia, or pain during sexual intercourse, is among the problems most frequently reported by postmenopausal women $(1,2)$. For women of all ages, dyspareunic pain often results in distress, decreased sexual functioning and enjoyment, relationship difficulties and reduced quality of life (3-5). For postmenopausal women, dyspareunia may also accentuate personal issues related to aging, body image and health.

As with most female sexual difficulties occurring during midlife and beyond, dyspareunia is typically considered to be a consequence of declining ovarian hormone levels $(6,7)$. As a result of aging tissue and decreasing levels of endogenously produced estrogens during menopause, in particular estradiol $\left(E_{2}\right)$, atrophic changes may be observed in the external genital

\section{Dyspareunie chez les femmes post- ménopausées : Analyse critique}

HISTORIQUE : La dyspareunie, ou douleur lors des rapports sexuels, est parmi les problèmes les plus souvent signalés chez les femmes postménopausées. Par le passé, la littérature a presque toujours attribué la douleur de la dyspareunie durant ou après la ménopause à un déclin des taux d'œstrogènes et à l'atrophie vaginale.

OBJECTIFS : Procéder à une analyse critique de la littérature sur la prévalence, les facteurs de risque, l'étiologie, le tableau clinique et le traitement de la dyspareunie postménopausique. La présente synthèse se penche également sur la conceptualisation traditionnelle et largement acceptée de la dyspareunie postménopausique en tant que symptôme direct d'une baisse hormonale.

MÉTHODES : Les auteurs ont interrogé des bases de données de médecine et de psychologie pour recenser les articles pertinents et les études empiriques. La qualité méthodologique et les issues des études ont été évaluées systématiquement

RÉSULTATS : Selon les preuves empiriques disponibles, la dyspareunie serait fréquente chez les femmes postménopausées et elle n'est pas en forte corrélation avec le statut ménopausique, les taux d'œstrogènes ou l'atrophie vaginale. Des taux moindres d'œstrogènes endogènes contribuent à l'apparition de la dyspareunie chez les femmes postménopausées qui souffrent d'atrophie vaginale. Les suppléments hormonaux permettent de soulager la douleur. Par contre, une proportion substantielle des femmes traitées n'en obtiennent pas de soulagement.

CONCLUSION : La dyspareunie postménopausique qui survient avec l'atrophie vaginale est fortement associée à un déficit œstrogénique au niveau des voies génitales. Par contre, un pourcentage significatif de femmes postménopausées manifestent des douleurs de dyspareunie qui ne sont pas causées par l'hypo-œstrogénisme. Il est probable que d'autres types de dyspareunie, déjà présents en préménopause, affectent également les femmes postménopausées. Il faudra effectuer des recherches pour clarifier adéquatement cette question. Les auteurs proposent un changement de perspective axé davantage sur une approche multidimensionnelle de la douleur, en vue des recherches futures sur la dyspareunie chez les femmes postménopausées.

region, introitus and vagina (ie, vaginal atrophy). The resulting symptoms may include itching, vulvar pruritus, vaginal dryness and dyspareunia (8). Not surprisingly, medical and pharmaceutical attention has focused on postmenopausal dyspareunia and its relationship to estrogens. Consequently, hormone replacement therapy (HRT) has long been considered the frontline and almost exclusive treatment for painful intercourse in postmenopausal women $(7,9)$. Considering the many other factors that may negatively affect sexual functioning in postmenopausal women, such as increased likelihood of health problems, pelvic floor muscular dysfunction, dermatological conditions, relationship factors, partner's health and psychosocial stressors relevant to midlife (eg, role changes within the

${ }^{1}$ Department of Psychology, McGill University; ${ }^{2}$ Department of Psychology, Sex and Couple Therapy Service, McGill University Health Centre

(Royal Victoria Hospital); ${ }^{3}$ Department of Obstetrics and Gynecology, Sir Mortimer B Davis Jewish General Hospital, Montreal, Quebec

Correspondence: Ms Alina Kao, Department of Psychology, McGill University, 1205 Docteur Penfield Avenue, Montreal, Quebec H3A 1 B1 .

Telephone 514-398-5323, fax 514-398-4896, email akao@ego.psych.mcgill.ca 


\begin{tabular}{|c|c|}
\hline $\begin{array}{l}\text { Reproductive event } \\
\text { or phase }\end{array}$ & Definition \\
\hline Premenopause & Reproductive phase preceding perimenopause \\
\hline $\begin{array}{l}\text { Perimenopause } \\
\text { (also termed } \\
\text { climacteric) }\end{array}$ & $\begin{array}{l}\text { The period before the menopause with biological, } \\
\text { endocrinological and clinical features of } \\
\text { impending menopause. Minimally, a period of } \\
\text { one year following the final menses should also } \\
\text { be included in this phase. }\end{array}$ \\
\hline Menopause & $\begin{array}{l}\text { The permanent cessation of menstruation } \\
\text { resulting from the loss of ovarian follicular activity }\end{array}$ \\
\hline Postmenopause & $\begin{array}{l}\text { Reproductive phase commencing from the time } \\
\text { of the menopause. However, this period } \\
\text { cannot be ascertained until a full } 12 \text { months of } \\
\text { spontaneous amenorrhea have passed. }\end{array}$ \\
\hline
\end{tabular}

Data from reference 16

family, caring for elderly parents, retirement), this seems to be an oversimplified and one-dimensional view of dyspareunia in postmenopausal women. Moreover, vulvar and pelvic pain conditions commonly affecting premenopausal women (eg, provoked vestibulodynia, vulvodynia, vaginismus) may also exist in postmenopausal women and have been more or less ignored. This seems odd because the main presenting complaint is pain. The lack of interest in the actual pain is reflected by the almost total absence of clinical or research reports about postmenopausal dyspareunia in the pain literature. The present review examines the traditional and widely held conceptualization of postmenopausal dyspareunia as a relatively direct symptom of hormonal decline.

To identify research relevant to the present review, searches of the electronic databases PsycInfo, MEDLINE, Biosis and Excerpta Medica were performed for articles and empirical studies published in English-language journals between January 1969 and August 2007 concerning the prevalence, etiology or treatment of dyspareunia in perimenopausal or postmenopausal women. Hence, the keywords dyspareunia, coital pain, sexual function, sexuality, sexual dysfunction, vaginitis, urogenital, genital or vaginal were combined with the keywords menopause, climacteric, perimenopause, postmenopause, aging, hormone, estrogen or hormone therapy. In addition, a manual search of pertinent books, journals and a review of the reference sections of included papers was performed. The first author performed database searches, reviewed germane articles to extract research findings and evaluated study quality by the type of research protocol used. The coauthors were involved in the research evaluation and verification process.

\section{GENERAL METHODOLOGICAL ISSUES}

Before discussing the available evidence, it is important to consider general methodological issues that were commonly encountered in the reviewed articles. In critically assessing the past literature, differences in study design and subject variables made it difficult to compare or aggregate findings from different investigations. For example, a widespread shortcoming of the reviewed literature was the failure to report or distinguish between reproductive stages (eg, 10-15). Age alone, and not menstrual status, was often used to gauge the reproductive phases of participants. This is problematic, because there is a large variance in the age at which individual women experience menopause. As such, the effects of age and menopause were confounding variables in these investigations. Moreover, discrepancies existed in how reproductive phases were defined. The World Health Organization (16) suggested the standardized definitions for the stages of the female reproductive life cycle listed in Table 1. These World Health Organization definitions will be used in the present review unless otherwise specified.

Another common methodological limitation of the literature was the failure to indicate whether women were on HRT (eg, 4,17-21). If HRT was specified, studies often failed to distinguish between the varying replacement regimens which can have potentially different effects on the urogenital system and sexual functioning (eg, 22-24). Studies often also failed to differentiate between surgically and naturally menopausal women (eg, 20,25-27). This is an important factor to consider because hysterectomy and oophorectomy may cause altered sexual response and functioning (28-30).

The failure to use standardized measures of pain and sexuality was another frequent limitation of the literature (eg, $17,22,31,32)$. Standardized and validated pain measures, such as the McGill-Melzack Pain Questionnaire (33), were never used. Also, although there are few standardized and validated assessment instruments of female sexual dysfunction for use in postmenopausal women, such as the McCoy Female Sexuality Questionnaire (34) and the Female Sexual Function Index (35), their use would have been valuable in disentangling the occurrence of different problems. For example, the symptoms of lack of lubrication during intercourse and pain during intercourse were often grouped together (eg, 20,36-39). These problems can occur separately and may have different causes.

\section{PREVALENCE}

Population-based prevalence studies of dyspareunia were heterogeneous in research methodologies and sample populations. Many studies included women who were likely to be postmenopausal because they were middle-aged or older. They could not be integrated into the present summary because they did not report or separately analyze findings by reproductive phase (eg, 10-15,40). Studies were also excluded if they clustered other symptoms, such as lack of lubrication or vaginal dryness, together with dyspareunia (eg, 36,37).

As Table 2 illustrates, findings from population-based studies are disparate. Estimates of point prevalence of postmenopausal dyspareunia derived from large-scale studies range from $2 \%$ (22) to $29 \%$ (41). Recent studies (eg, 24,41) have obtained higher prevalence estimates than older investigations (eg, 17,18), which may be, in part, a product of changing attitudes about sexual functioning in aging populations. For example, some studies only queried sexually active women about sexual difficulties or pain during intercourse (eg, 18,42). As such, they may have under-represented their findings, because many women do not engage in sexual activity because it is too painful. On the other hand, the differences may, at least in part, reflect sociocultural, lifestyle, biological and variations of reporting methods among differing populations. For example, major international differences in rates of dyspareunia in 40- to 80 -year-old women have been found in a global investigation of 29 countries (15). The Northern European countries had the lowest point prevalence (5\%), while the Southeast Asian countries had the highest (22\%). Moreover, ethnic differences 
TABLE 2

Prevalence of dyspareunia in population-based samples of perimenopausal and/or postmenopausal women

\begin{tabular}{|c|c|c|c|c|c|c|}
\hline Study & $\begin{array}{l}\text { Subjects, } \\
\text { age (years), } \\
\text { recruitment }\end{array}$ & $\begin{array}{l}\text { Reprod- } \\
\text { uctive } \\
\text { phases }\end{array}$ & $\begin{array}{l}\text { M } \\
\text { of } \\
\text { ad } \\
\end{array}$ & $\begin{array}{l}\text { Measurement } \\
\text { f dyspareunia, } \\
\text { idministration, } \\
\text { question (if } \\
\text { reported) }\end{array}$ & $\begin{array}{l}\text { Prevalence of } \\
\text { dyspareunia }\end{array}$ & Methodological problems \\
\hline $\begin{array}{l}\text { Rekers et al, } \\
1992 \text { (18) }\end{array}$ & $\begin{array}{l}n=1299 \\
35-80 \\
a\end{array}$ & $1,2,3$ & $\begin{array}{l}\text { Not } \\
\text { specified/ } \\
\text { not clear }\end{array}$ & $2 a$ & $\begin{array}{l}\text { 6.2\% premenopausal } \\
\text { women; } \\
16.1 \% \text { postmeno- } \\
\text { pausal women }\end{array}$ & $\begin{array}{l}\text { Did not report rate of dyspareunia in sexually inactive women; } \\
\text { did not report data collected from perimenopausal women; } \\
\text { did not report whether HRT users were included; location of } \\
\text { dyspareunic pain not assessed; did not separately analyze } \\
\text { data from different age groups }\end{array}$ \\
\hline $\begin{array}{c}\text { Barlow et al, } \\
1997 \text { (22) }\end{array}$ & $\begin{array}{l}n=2045 \\
55-85+ \\
b\end{array}$ & $3 c, 3 d$ & $\begin{array}{l}\text { Mixed } \\
\text { (types not } \\
\text { specified) }\end{array}$ & $2 a$ & $\begin{array}{l}2 \% \text { overall in past } \\
2 \text { years }\end{array}$ & $\begin{array}{l}\text { Did not distinguish between vaginal dryness and soreness; did } \\
\text { not separately analyze data from HRT users and nonusers, } \\
\text { women in different age groups or surgically menopausal } \\
\text { women from naturally menopausal women; location of } \\
\text { dyspareunic pain not assessed; reported results unclear }\end{array}$ \\
\hline $\begin{array}{c}\text { Barlow et al, } \\
1997(23)\end{array}$ & $\begin{array}{l}n=3062 \\
55-75 \\
a\end{array}$ & $1,2,3 c, 3 d$ & $\begin{array}{l}\text { Mixed } \\
\text { (types not } \\
\text { specified) }\end{array}$ & $\begin{array}{l}2 a \\
5 \text {-point } \\
\text { scale rating } \\
\text { severity of } \\
\text { "problems } \\
\text { with painful } \\
\text { sex/sexual } \\
\text { relations" }\end{array}$ & $\begin{array}{l}2.2 \% \text { overall } \\
6.7 \% \text { dyspareunia since } \\
\text { onset of menopause; } \\
\text { significantly less } \\
\text { dyspareunia in older } \\
\text { women }\end{array}$ & $\begin{array}{l}\text { Did not separately analyze data from HRT users and nonusers } \\
\text { or women in different reproductive phases; location of } \\
\text { dyspareunic pain not assessed }\end{array}$ \\
\hline $\begin{array}{l}\text { Borissova et al, } \\
2001 \text { (24) }\end{array}$ & $\begin{array}{l}n=627 \\
51.2 \pm 5 \\
c\end{array}$ & $\begin{array}{l}1,2 ?, 3 a \\
3 b, 3 c \\
3 d\end{array}$ & $\begin{array}{l}\text { Mixed } \\
\text { (types not } \\
\text { specified) }\end{array}$ & $2 a$ & $\begin{array}{l}14.7 \% \text { overall } \\
12 \% \text { premenopausal } \\
\text { women; } \\
16.1 \% \text { postmeno- } \\
\text { pausal women on } \\
\text { HRT; } 21.5 \% \text { post- } \\
\text { menopausal women } \\
\text { not on HRT }\end{array}$ & $\begin{array}{l}\text { Method of recruitment could have produced response biases } \\
\text { which make data not representative of actual population } \\
\text { prevalence; location of dyspareunic pain not assessed; small } \\
\text { HRT sample size }(n=36) \text {; perimenopausal women not } \\
\text { assessed separately }\end{array}$ \\
\hline $\begin{array}{l}\text { Cain et al, } \\
2003(42)\end{array}$ & $\begin{array}{l}n=3262 \\
42-52 \\
d\end{array}$ & 1,2 & No & $2 a$ & $\begin{array}{l}21.1 \% \text { overall } \\
17.3 \% \text { premeno- } \\
\text { pausal women; } \\
25.1 \% \text { perimeno- } \\
\text { pausal women }\end{array}$ & $\begin{array}{l}\text { Did not report rate of dyspareunia in sexually inactive women } \\
\text { ( } 21 \% \text { of sample); did not ask if sexual inactivity was due to } \\
\text { dyspareunia; location of dyspareunic pain not assessed }\end{array}$ \\
\hline $\begin{array}{l}\text { Castelo-Branco } \\
\text { et al, } 2005 \text { (94) }\end{array}$ & $\begin{array}{l}n=125 \\
35-54 \\
a\end{array}$ & $\begin{array}{l}1,2,3 a \\
3 b, 3 c \\
3 d\end{array}$ & $\begin{array}{l}\text { Mixed } \\
\text { (types not } \\
\text { specified) } \\
(\text { HRT } n=3)\end{array}$ & ) & $\begin{array}{l}40 \% \text { dyspareunia in } \\
\text { peri- and } \\
\text { postmenopausal } \\
\text { women }\end{array}$ & $\begin{array}{l}\text { Perimenopausal women not assessed separately from } \\
\text { postmenopausal women; did not report rates of dyspareunia } \\
\text { in premenopausal women; location of dyspareunic pain not } \\
\text { assessed }\end{array}$ \\
\hline
\end{tabular}

Age presented as mean $\pm S D$ and/or range. All studies were cross-sectional. Recruitment: a Random selection (eg, from a census), $b$ Representative sample of a specific population, c Volunteer (eg, from advertisements), d Convenience sample (eg, subsample from an ongoing study); Reproductive phases: 1 Premenopausal, 2 Perimenopausal, 3 Postmenopausal, 3a Early postmenopausal, 3b Late postmenopausal, 3c Naturally postmenopausal specified, 3d Surgically postmenopausal specified; Measures of dyspareunia: 2 Adhoc structured questionnaire or interview; Administration: a Face-to-face, $b$ Telephone, $c$ Postal. HRT Hormone replacement therapy

in reported rates of dyspareunia in premenopausal and perimenopausal women have also been found (42). The most recent population-based prevalence investigations specifically examining postmenopausal women not taking HRT estimated that between $21.5 \%$ and $29 \%$ suffer from dyspareunia $(24,41)$. Studies with large sample sizes that included HRT users and nonusers obtained lower prevalence estimates of postmenopausal dyspareunia, ranging from $2 \%$ to $6.7 \%(22,23)$.

Patient population prevalence studies are important because they help to elucidate the clinical load of a particular problem in the health care setting. Similar to population-based studies, Table 3 demonstrates that findings on the prevalence 
of postmenopausal dyspareunia in outpatient samples were discrepant across investigations; they range from $11 \%$ (25) to $45.3 \%$ (43), and generally fell between $35 \%$ and $45 \%$. The reported range of clinical outpatient rates was remarkably greater than the range stemming from nonclinical samples (ie, $2 \%$ to $29 \%)(23,41)$. One reason for this difference in reporting may be that women may perceive dyspareunia as a 'valid' medical problem when it is being queried in the context of a health care setting. As a result, they may feel less embarrassed about disclosing pain experienced during sexual intercourse. Alternatively, dyspareunia may be one of the reasons women seek treatment in special clinics. Because of this possibility, it is important to remark that a significant proportion of treatmentseeking postmenopausal women report dyspareunia when asked.

\section{CLINICAL PRESENTATION}

Subtypes of premenopausal dyspareunia can be categorized by differences in location, intensity, temporal pattern and sensory quality (44). These variables are similar to those used in the pain classification system advocated by the International Association for the Study of Pain (45) as well as the International Society for the Study of Vulvovaginal Disease (46) and are considered useful markers for different etiologies (47). However, very limited data is available on the clinical description of dyspareunia affecting postmenopausal women. By and large, investigations have failed to assess the anatomical location of pain experienced during intercourse and have not enquired about specific pain characteristics in postmenopausal women.

Two somewhat vague anatomical locations of dyspareunic pain, 'superficial' (ie, external genital) and 'deep' (ie, internal genital or pelvic), have been assessed in postmenopausal women. Superficial provoked pain on contact, particularly in the vulvar area, is the most common form of premenopausal dyspareunia, affecting an estimated $12 \%$ of women (48). From the meagre data available, superficial dyspareunia also seems be the most frequently occurring subtype later in life, affecting an estimated $8.5 \%$ of women 50 years of age or older (reproductive phase not reported) in the general population (48). The preponderance of superficial pain is also found in clinical populations, and is estimated to affect $22 \%$ of clinical samples of perimenopausal and postmenopausal women (27), and 32\% of gynecological outpatients 50 years of age or older (12). However, whether the preponderance of such cases includes vulvar pain is unknown. Although there is a paucity of information about deep dyspareunia in the general population of postmenopausal women, it has been found to be less prevalent than superficial dyspareunia in clinical samples. Estimated rates of deep pain during intercourse range between $8 \%$ and $16 \%$ in outpatient samples $(27,12)$.

Intensity of postmenopausal dyspareunic pain was assessed in a sole study examining a group of gynecological outpatients and volunteers; it was found that the majority of sufferers, $37.4 \%$ of women living with their spouses, experienced slight pain or discomfort, while $6.1 \%$ of women living with their spouses had moderate to severe pain (21). At the time of writing, only one study has investigated the sensory quality of dyspareunic pain in middle-aged women; although feelings of either sharp contact pain, or itching or burning sensations were endorsed, there was no enquiry about other types of pain (eg, aching, pinching, stretching) (48). Even though data concerning the clinical presentation of postmenopausal dyspareunia are scarce, it would seem from the information available that there is variation in the location and sensory quality of pain $(12,48,49)$. It appears that the most common subtype is superficial provoked pain that has a sharp or burning quality, which is remarkably similar to provoked vestibulodynia (also known as vulvar vestibulitis syndrome), the most common form of dyspareunic pain in premenopausal women.

\section{RISK FACTORS AND ETIOLOGY}

In the past decade, the literature concerning the causes of premenopausal dyspareunia has rapidly grown. Numerous etiological and maintaining mechanisms, both organic and psychological, have been proposed (eg, history of recurrent yeast infections, elevated genetic susceptibility to inflammatory disorders, heightened anxiety and stress) (47,50-52). However, this growth in the premenopausal etiological literature has not carried over to postmenopausal dyspareunia. Comparable dyspareunic pain occurring during or after the menopausal transition has almost unanimously been attributed to aging, decreased estrogen levels in the genital tract, and resulting vaginal dryness and atrophy (53). Related to these changes, decreased sexual arousal and lack of lubrication are other proposed mechanisms responsible for pain during intercourse (7).

\section{Age}

The process of aging involves not only hormonal alterations, but also other physiological, psychological and social changes that can compromise women's sexual functioning and activities (54). Although the findings have been mixed, the majority of large-scale cross-sectional studies (ie, $n>1000$ ) report that the occurrence of dyspareunia decreases with age. Two crosssectional studies of women between the ages of 18 and 59 years found that reports of dyspareunia decreased with increasing age $(n=1622$ [13]; $n=908$ [14]). However, this seems to mirror a decline in the number of women engaging in sexual activity with progressing age in the American sample (55). Parallel declines in pain and overall sexual activity were also found with age in a British cohort of postmenopausal women $(n=2045)$ (22). A pan-European study with a sample of 3062 women between 55 and 75 years of age reported significantly lower rates of dyspareunia in older women (23). On the other hand, two cross-sectional studies that included wide participant age ranges (ie, 12 to 78 years old, $n=887 ; 35$ to 59 years old, $n=436$ ) found that the frequency of dyspareunia increased with the age of the population $(11,12)$. A third cross-sectional and longitudinal study $(n=201)$ also presented findings of increased prevalence of combined dyspareunia and vaginal dryness with age (39), although whether dyspareunia specifically increased was not reported. Another study found that the occurrence of dyspareunic pain fluctuated with increasing age $(n=1761)(40)$. Although women 60 to 65 years of age reported more dyspareunia than those between 50 and 55 years of age, the rates decreased and stabilized for women older than 65 years. However, Weber et al $(n=104)$ (56) found no age differences between outpatient women who reported dyspareunia, vaginal dryness or both, and women who did not have either symptom. Evidence from the majority of large-scale cross-sectional investigations suggests that increasing age may be associated with decreased rates of dyspareunia $(13,22,23)$, but this may be ascribed in part to declining sexual activity in older women.

\section{Reproductive phase}

The influence of the menopausal transition is often confounded by aging if these variables are not statistically controlled for in 
TABLE 3

Prevalence of dyspareunia in clinical samples of perimenopausal and/or postmenopausal women

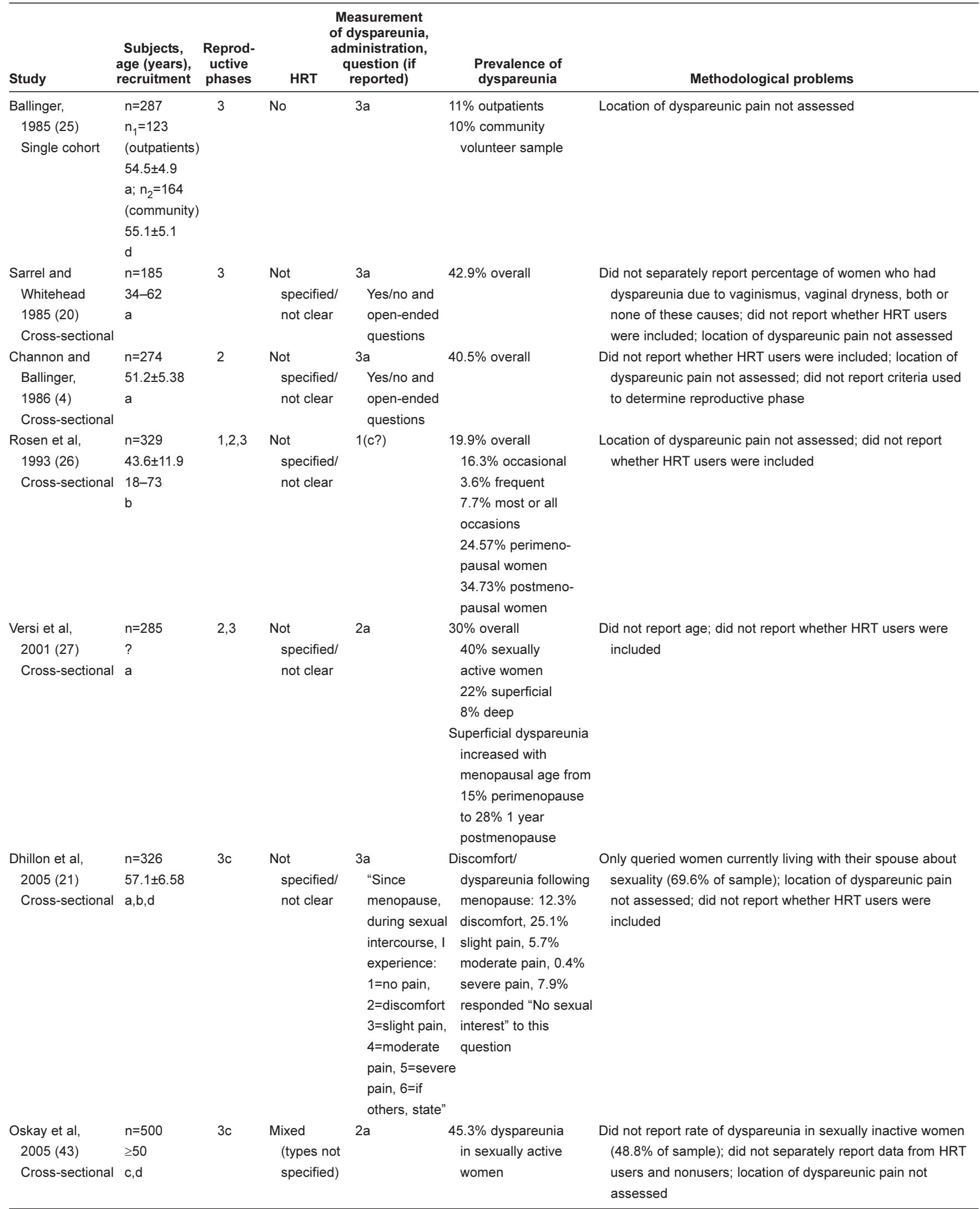

Age presented as mean $\pm S D$ and/or range. Recruitment: a Menopause clinical outpatient, b Gynecological clinical outpatient, $c$ Hospital outpatient, $d$ Volunteer Reproductive phases: 1 Premenopausal, 2 Perimenopausal, 3 Postmenopausal, 3c Naturally postmenopausal specified, 3d Surgically postmenopausal specified; Measures of dyspareunia: 1 Standardized structured questionnaire, 2 Adhoc structured questionnaire or interview, 3 Adhoc semistructured interview; Administration a Face-to-face, c Postal. HRT Hormone replacement therapy 
studies of midlife sexual functioning. Menopausal status, independent of the effects of aging, has been associated with a reported "decline in sex life" and difficulties with intercourse (57). There is some evidence in the reviewed literature that suggests part of these difficulties involve pain and that women experience dyspareunia with augmented frequency after menopause. For example, the prospective Melbourne Women's Midlife Health Project found that dyspareunia became significantly more frequent as women went from the premenopausal to the postmenopausal phase $(58,59)$. Moreover, Moore and Kombe (38) found a greater occurrence of dyspareunia in women in late menopause (ie, six to 10 years postmenopause) compared with early menopausal women. A cross-sectional investigation showed that superficial, not deep, dyspareunic pain increased with menopausal status (27).

On the other hand, findings from several other investigations suggest that menopause may not be the main risk factor for the development of dyspareunia. For example, Rekers et al (18) found that despite an increased rate of dyspareunia in sexually active postmenopausal women, the overall rate of vaginal pain was similar for women in the premenopausal and postmenopausal phases. By separately analyzing women in different reproductive stages, Rosen et al (26) found that pain during intercourse affected $24.5 \%$ of premenopausal women, $24.6 \%$ of perimenopausal women and $34.7 \%$ of postmenopausal women. However, the increased rate of dyspareunia in postmenopausal women was not large enough to be statistically significant. Furthermore, no direct relationship was found between later reproductive phases and dyspareunia in three other investigations $(17,56,60)$. Although there is some evidence from the reviewed research suggesting that women do experience coital pain more frequently after menopause, there are a comparable number of contrary findings reported. This makes it difficult to conclude whether dyspareunia is affected by reproductive stage and calls into question the existence of a specifically postmenopausal dyspareunic syndrome.

\section{Decreasing hormones and vaginal atrophy}

Although decreasing levels of endogenously produced hormones are the hallmark of the menopausal transition and are thought to be directly linked to postmenopausal dyspareunic pain, only five studies were found that actually examine their association (59-63). Table 4 summarizes findings from research on the relationship among dyspareunia, hormone levels and vaginal atrophy in postmenopausal women. Vaginal atrophy is a manifestation of aging tissue, and the cytological and chemical transformations in the genital region that result from declining levels of estrogens, particularly $\mathrm{E}_{2}$, during menopause. It is purported to be the primary cause of postmenopausal dyspareunia (53). Furthermore, lack of estrogen can also lead to vaginal narrowing and shortening, thereby increasing the likelihood of painful intercourse (64). Moreover, the drop in circulating estrogens is thought to be the cause of vascular changes resulting in diminished physiological arousal to sexual stimulation and lack of lubrication, which consequentially lead to dyspareunia (7).

In examining eight years of longitudinal data from the Melbourne Women's Midlife Health Project, Dennerstein et al (59) used structural equation modelling to demonstrate that declining $\mathrm{E}_{2}$ affects dyspareunia. This model predicts that increasing $\mathrm{E}_{2}$ levels equivalent to those in premenopausal women at midcycle would be necessary to decrease dyspareunia. On the other hand, the previous level of dyspareunia was also a major determining factor that predicted current coital pain. This was the only study found in the postmenopausal literature to examine pre-existing dyspareunia. Although the duration of previous levels of dyspareunia was not specified, the results suggest that many postmenopausal women in this sample did not develop dyspareunia solely due to declining estrogen. It is possible that a proportion of postmenopausal women developed dyspareunia before menopause. Another study (60) reported that menopausal status and lowered $\mathrm{E}_{2}$ were associated with dyspareunia. In contrast, three other studies found no direct relationship between estrogen levels and reports of dyspareunia (61-63); it is possible that due to their smaller sample sizes, these studies lacked sufficient statistical power to detect subtle effects of $E_{2}$. No evidence of association was found between dyspareunic pain and levels of testosterone, androgens, follicle stimulating hormone or luteinizing hormone $(61,63)$, which are hormones generally associated with sexual functioning.

The occurrence of dyspareunic pain in postmenopausal women has, by and large, been ascribed to tissue aging and the progressively atrophizing effects of declining estrogens within the female genitalia. Yet, in examining the reviewed articles (Table 4), not one study concluded that dyspareunia in postmenopausal women was associated with either occurrence or severity of vaginal atrophy $(56,61,63)$.

Although lower $\mathrm{E}_{2}$ levels may contribute to the development of dyspareunia in postmenopausal women, a direct association has not consistently been found. Vaginal atrophy, a sequela of the lack of estrogens in the genital region, has also not been found to be associated with dyspareunia. These findings suggest that other nonhormonal causal factors may be involved in the development of dyspareunia in postmenopausal women.

\section{Decreased arousal and lack of lubrication}

Decreased physiological arousal and lack of lubrication during intercourse are frequently reported sexual difficulties in menopause and are commonly attributed to decreasing estrogen levels (7). Certainly, lack of lubrication increases friction during intercourse and can lead to pain $(7,39)$. Although inadequate lubrication has been thought by some to be the chief cause of postmenopausal dyspareunic pain, the prevalence of lubrication difficulties has been found to increase with age (14) or remain stable (13), while the majority of large-scale studies found that dyspareunia decreased with age $(13,14,22,23)$. Moreover, a psychophysiological investigation using vaginal photoplethysmography demonstrated that although baseline vasculogenic differences exist between postmenopausal women who reported moderate dyspareunia and premenopausal women, both groups showed similar genital responsivity to visual erotic stimuli (63). The available evidence suggests that even though lack of lubrication and physiological arousal may cause coital pain, their association with dyspareunia in postmenopausal women is weak.

\section{Pelvic floor abnormalities}

Pelvic floor abnormalities have been associated with menopause $(65,66)$. The pelvic floor musculature can be pathologically dys-synergistic, hypertonic or hypotonic (67). Postmenopausal women are more commonly affected by pelvic floor hypotonus $(65,66,68)$. This may cause deep dyspareunia due to lack of pelvic stability (67). Furthermore, pelvic floor functioning abnormalities may develop consequent to an initial 
TABLE 4

Relationship among hormone levels and/or vaginal atrophy and dyspareunia in perimenopausal and postmenopausal women

\begin{tabular}{|c|c|c|c|c|c|c|c|c|}
\hline Study & $\begin{array}{l}\text { Subjects, } \\
\text { age (years), } \\
\text { recruitment }\end{array}$ & $\begin{array}{l}\text { Reprod- } \\
\text { uctive } \\
\text { phases }\end{array}$ & HRT & $\begin{array}{l}\text { Hormonal } \\
\text { assays }\end{array}$ & $\begin{array}{l}\text { Hormonal assay } \\
\text { outcomes and } \\
\text { dyspareunia }\end{array}$ & $\begin{array}{c}\text { Measure of } \\
\text { vaginal atrophy }\end{array}$ & $\begin{array}{l}\text { Vaginal atrophy } \\
\text { and dyspareunia } \\
\text { results }\end{array}$ & $\begin{array}{l}\text { Methodological } \\
\text { problems }\end{array}$ \\
\hline $\begin{array}{l}\text { James et al, } \\
1984(61) \\
\text { Single cohort }\end{array}$ & $\begin{array}{l}n=96 \\
54-56 \\
b\end{array}$ & $2,3 c$ & No & $\begin{array}{l}\mathrm{E}_{1}, \mathrm{E}_{2} \\
\quad \mathrm{FSH}, \mathrm{LH}\end{array}$ & $\begin{array}{l}\text { Cytology findings } \\
\text { unrelated to plasma } \\
\text { hormone levels }\end{array}$ & $\begin{array}{l}\text { Physical exam; } \\
\text { 5-point scale rating } \\
\text { severity of physical } \\
\text { signs of vaginal } \\
\text { atrophy; vaginal } \\
\text { cytology }\end{array}$ & $\begin{array}{l}\text { Level of vaginal } \\
\text { atrophy not } \\
\text { related to } \\
\text { dyspareunia } \\
\text { or vasomotor } \\
\text { symptoms }\end{array}$ & $\begin{array}{l}\text { Did not report rate } \\
\text { of dyspareunia in } \\
\text { sexually inactive } \\
\text { women }\end{array}$ \\
\hline $\begin{array}{l}\text { Cutler et al, } \\
1987 \text { (62) } \\
\text { Cross-sectional }\end{array}$ & $\begin{array}{l}n=52 \\
38-55 \\
d\end{array}$ & 2 & & $\mathrm{E}_{2}$ & $\begin{array}{c}E_{2} \text { levels not related } \\
\text { to dyspareunia }\end{array}$ & $\mathrm{n} / \mathrm{a}$ & $\mathrm{n} / \mathrm{a}$ & $\begin{array}{l}\text { Did not report rates } \\
\text { of dyspareunia }\end{array}$ \\
\hline $\begin{array}{l}\text { Weber et al, } \\
1995 \text { (56) } \\
\text { Cross-sectional }\end{array}$ & $\begin{array}{l}n=104 \\
55.8 \\
c\end{array}$ & $\begin{array}{l}1,2 ? \\
3 c, 3 d\end{array}$ & $\begin{array}{l}\text { Mixed } \\
\text { (types } \\
\text { specifie }\end{array}$ & $\mathrm{n} / \mathrm{a}$ & $\mathrm{n} / \mathrm{a}$ & $\begin{array}{l}\text { VAl; vaginal } \\
\text { cytology }\end{array}$ & $\begin{array}{l}\text { Rate of } \\
\text { dyspareunia not } \\
\text { related to } \\
\text { reproductive } \\
\text { phase, use of } \\
\text { ERT, vaginal } \\
\text { cytology results } \\
\text { or VAl score }\end{array}$ & $\begin{array}{l}\text { Did not separately } \\
\text { analyze data from } \\
\text { pre- and } \\
\text { perimenopausal } \\
\text { women; did not } \\
\text { report rates of } \\
\text { vaginal atrophy }\end{array}$ \\
\hline $\begin{array}{l}\text { Laan and } \\
\text { van Lunsen, } \\
1997(63) \\
\text { Cross-sectional }\end{array}$ & $\begin{array}{l}n=42 \\
54 \pm 4.5 \\
46-64 \\
d\end{array}$ & $3 c$ & No & $\begin{array}{l}\mathrm{E}_{1}, \mathrm{E}_{2}, \\
\mathrm{~A}, \mathrm{~T}, \text { free } \\
\text { androgen, } \\
\mathrm{FSH}, \mathrm{PRL}\end{array}$ & $\begin{array}{l}\text { Hormone levels } \\
\text { unrelated to } \\
\text { dyspareunia }\end{array}$ & $\begin{array}{l}\text { VAI; PFI; urogenital } \\
\text { complaints checklist }\end{array}$ & $\begin{array}{l}\text { Level of vaginal } \\
\text { st atrophy unrelated } \\
\text { to dyspareunia } \\
\text { or vaginal } \\
\text { dryness }\end{array}$ & $\begin{array}{l}\text { Did not report rates } \\
\text { of vaginal atrophy } \\
\text { or dyspareunia; } \\
\text { location of } \\
\text { dyspareunic pain } \\
\text { not reported; did } \\
\text { not report whether } \\
\text { premenopausal } \\
\text { comparison group } \\
\text { was matched }\end{array}$ \\
\hline $\begin{array}{l}\text { Avis et al, } \\
2000(60) \\
\text { Cross-sectional }\end{array}$ & $\begin{array}{l}n=200 \\
51-61 \\
e\end{array}$ & $1,2,3 c$ & No & $\begin{array}{r}\mathrm{E}_{1}, \mathrm{E}_{2} \\
\mathrm{FSH}\end{array}$ & $\begin{array}{l}\text { Variance accounted } \\
\text { for by } \mathrm{E}_{2} \text { levels in } \\
\text { conjunction with } \\
\text { menopausal status } \\
\text { was associated with } \\
\text { dyspareunia }\end{array}$ & $\mathrm{n} / \mathrm{a}$ & $\mathrm{n} / \mathrm{a}$ & $\begin{array}{l}\text { Did not separately } \\
\text { analyze data from } \\
\text { pre-, peri- and } \\
\text { postmenopausal } \\
\text { women }\end{array}$ \\
\hline $\begin{array}{l}\text { Dennerstein et al, } \\
2005 \text { (59) } \\
\text { Cross-sectional }\end{array}$ & $\begin{array}{l}n=336 \\
45-55 \\
\text { at baseline } \\
\text { e }\end{array}$ & $1,2,3 c$ & $\begin{array}{l}\text { Mixed } \\
\text { (types } \\
\text { specifie }\end{array}$ & $\begin{array}{l}\mathrm{E}_{2}, \mathrm{FSH} \\
\mathrm{T}, \mathrm{SHBG}\end{array}$ & $\begin{array}{l}\text { Dyspareunia was } \\
\text { predicted by previous } \\
\text { level of dyspareunia } \\
\text { and } \mathrm{E}_{2} \text { level }\end{array}$ & $\mathrm{n} / \mathrm{a}$ & $\mathrm{n} / \mathrm{a}$ & \\
\hline
\end{tabular}

Age presented as mean $\pm S D$ and/or range. Recruitment: b Representative sample of a specific population, c Gynecological outpatients, $d$ Volunteer (eg, from advertisements), e Subsample from an ongoing study; Reproductive phases: 1 Premenopausal, 2 Perimenopausal, 3c Naturally postmenopausal specified, 3d Surgically postmenopausal specified; A Androgen; $E_{1}$ Estrone; E Estradiol; ERT Estrogen replacement therapy; FSH Follicle stimulating hormone; HRT Hormone replacement therapy; LH Luteinizing hormone; n/a Not applicable; PFI Pelvic Floor Index; PRL Prolactin; SHBG Sex hormone binding globulin; T Testosterone; VAl Vaginal Atrophy Index

episode of dyspareunia triggered by a pathophysiological cause (eg, infection, vaginal atrophy, vestibulodynia). The pelvic floor dysfunction may persist after the original cause of dyspareunia has been treated and may become a maintaining factor of coital pain (69). At the time of writing, there are no studies that assessed the effect of pelvic floor functioning on dyspareunic pain in postmenopausal women.

Available etiological evidence suggests that some postmenopausal women may develop pain during intercourse associated with their menopausal transition status, impoverished $\mathrm{E}_{2}$ levels, decreased sexual arousal or lack of lubrication. However, the inconsistent nature of the reviewed findings suggests that other mechanisms may be involved. It is likely that, similar to premenopausal dyspareunia, multiple etiologies exist for postmenopausal dyspareunia and that these vary among women.

\section{TREATMENT}

HRT is widely considered to be the primary intervention for postmenopausal dyspareunia (70). It is suggested that women wishing to avoid the use of HRT should be offered nonhormonal vaginal moisturizer (ie, Replens, WellSpring Pharmaceutical, Canada) (70). Recommendations have been made for an integrated approach that may also include sex therapy, couple therapy and physical therapy $(64,67)$. However, these interventions have not been empirically evaluated for the treatment of postmenopausal dyspareunia.

Nonhormonal vaginal moisturizer

Replens, a polycarbophil-based vaginal moisturizing gel, is endorsed by the Canadian Obstetrics and Gynecology Society as the sole nonhormonal treatment for pain during intercourse 
in postmenopausal women (70). This recommendation is based on a comparative, randomized, open-label study which found Replens was as effective as a local estrogen cream in alleviating pain during intercourse in postmenopausal women with vaginal dryness (71). This investigation only assessed dypareunia in participants who engaged in sexual intercourse (ie, $n=11$ in each condition, pretreatment). At the end of treatment, fewer women were engaging in sexual intercourse than at the outset (ie, Replens $n=6$, dienestrol $n=9$ ), which indicates that some participants experiencing dyspareunia stopped having intercourse and were not considered in the final analysis. At the time of writing, there are no other investigations into the efficacy of nonhormonal vaginal moisturizers for the treatment of postmenopausal dyspareunia.

\section{HRT}

Estrogen replacement therapy is thought to offer relief from dyspareunia in postmenopausal women by reversing vaginal atrophy, increasing vaginal blood flow and promoting lubrication during intercourse (72). Both systemic and local administrations are prescribed for vaginal atrophy symptoms, but direct application onto the affected genital area is favoured because it is associated with fewer adverse events and directly targets affected tissue. Current guidelines offered by The Joint Committee Clinical Practice Gynaecology and Urogynaecology (70) of the Canadian Obstetrics and Gynecology Society state that postmenopausal women experiencing local symptoms of vaginal atrophy, such as dyspareunia, can be prescribed either a conjugated estrogen cream, a sustained-release intravaginal $E_{2}$ ring or a low-dose $E_{2}$ tablet. Recently, a position statement by the North American Menopause Society and a Cochrane literature review both reiterated these recommendations $(73,74)$. As such, only research into the efficacy of these specifically recommended forms of estrogen replacement is discussed in the present review. Use of other preparations of topical and systemic hormonal therapies (eg, oral formulations of estrogen supplementation with or without progesterone, tibolone, transdermal $E_{2}$ ) to alleviate dyspareunia in samples of postmenopausal women, generally suffering from vaginal atrophy, have also been investigated (eg, 75-80). The majority of published clinical studies examining these alternate forms of hormonal supplementation for the treatment of postmenopausal dyspareunia reported positive results regarding mean improvement. However, these preparations cause increased systemic hormonal absorption and are not recommended if urogenital symptoms, such as dyspareunia, are the primary complaint.

All reviewed treatment studies demonstrated beneficial effects of recommended estrogen replacement therapies on dyspareunia in postmenopausal women with vaginal atrophy (Table 5). While most were open label, or single-blinded, randomized, parallel-group investigations, three methodologically superior trials used a double-blind, randomized, placebocontrolled design $(31,32,81)$.

In examining randomized parallel-group trials, the continual release vaginal $E_{2}$ ring produced response rates (ie, percentage of sufferers reporting symptom improvement) that fell between $75 \%$ and $93 \%$ and cure rates (ie, percentage of women reporting complete alleviation of symptoms) ranged from $61 \%$ to $75 \%(82-85)$.

Randomized parallel-group trials have also shown that conjugated estrogen cream is superior to oral estrogens for the treatment of dyspareunia; it promoted better genital vascularization and produced improvement in $70 \%$ of hysterectomized women (86). Furthermore, it was found to be as effective as the vaginal $\mathrm{E}_{2}$ ring in alleviating dyspareunia in naturally postmenopausal women with vaginal atrophy. Approximately $77 \%$ of sufferers reported improvement and 57\% reported being cured (83).

A key methodological issue within the reviewed treatment literature is that many clinical trials are not double-blinded, randomized, placebo-controlled trials; they compare outcome to baseline symptom levels. Without a placebo control, the extent of improvement due to placebo effect is unknown $(87,88)$ and can be considerable. For example, three reviewed double-blinded, randomized, placebo-controlled investigations examined recommended forms of localized estrogen therapy $(31,32,81)$ and their positive findings on the beneficial effects of estrogen replacement for postmenopausal dyspareunia are in line with the aforementioned single-blind and parallel group studies. Two of the three studies found that low-dose $\mathrm{E}_{2}$ tablets improved dyspareunia in $73.1 \%$ to $81.2 \%$ of sufferers $(32,81)$. The third study demonstrated that treatment with the continual release intravaginal $E_{2}$ ring alleviated dyspareunia in $90 \%$ of sufferers (31). However, these investigations found that between $27 \%$ and $47 \%$ of sufferers reported relief of dyspareunia in the placebo control groups $(31,32,81)$.

Although the double-blinded, randomized, placebocontrolled trials were methodologically more rigorous compared with other reviewed investigations, several significant methodological problems should be highlighted. For example, although Simunic et al (32) produced the most comprehensive of these types of studies, the study still suffers from significant methodological problems. Dyspareunia was measured in a categorical fashion (ie, presence versus absence) rather than on a continual scale (ie, none, mild, moderate, severe), which may result in a distortion of reported treatment effects. Furthermore, 45 women in the $E_{2}$ treatment group dropped out of the study and an intent-to-treat analysis was not performed; this may have inflated the treatment response rate. Level of sexual activity is often used as a marker of functional improvement in studies examining symptoms that affect sexual functioning, but this was not measured. Also, the statistical analyses used - paired sample $t$ tests - were quite simplistic. These analyses probably inflated type I error and did not take into account the covariance of other vaginal atrophy symptoms or correct for multiple comparisons. Moreover, because this trial only included postmenopausal women with vaginal atrophy, little is known about the efficacy of the studied treatment for dyspareunia that occurs independent of this condition. Given these issues, even though this study is the best clinical trial to date and provides important evidence supporting the use of estrogen, it is not definitive.

It is important to note that all but one of the reviewed treatment studies (86) reporting on the effects of local HRT in postmenopausal dyspareunia exclusively recruited women with vaginal atrophy. However, because evidence for the associations among pain during intercourse, vaginal atrophy and hormone levels is weak, it is possible that these studies do not capture the full scope of dyspareunia occurring after menopause. Although it is estimated that between $20 \%$ and $60 \%$ of postmenopausal women do not have vaginal atrophy $(27,89)$, there is a paucity of treatment information about postmenopausal dyspareunia that does not occur concurrently with vaginal atrophy. Also, many treatment outcome studies only reported group means, and while improvement was generally reported to be significant, whether this was due to outliers or whether most women 
TABLE 5

Effect of recommended estrogen supplementations on dyspareunia in postmenopausal women

\begin{tabular}{|c|c|c|c|c|c|c|}
\hline Study & HRT & $\begin{array}{l}\text { Subjects, } \\
\text { age (years), } \\
\text { recruitment }\end{array}$ & $\begin{array}{l}\text { Inclusion } \\
\text { criteria, } \\
\text { reproductive } \\
\text { phases }\end{array}$ & $\begin{array}{l}\text { Measurement } \\
\text { of dyspareunia, } \\
\text { administration }\end{array}$ & $\begin{array}{l}\text { Dyspareunia } \\
\text { results }\end{array}$ & $\begin{array}{l}\text { Methodological } \\
\text { problems }\end{array}$ \\
\hline $\begin{array}{l}\text { Eriksen and } \\
\text { Rasmussen, } \\
1992 \text { (81) } \\
\text { Double-blind, } \\
\text { randomized, } \\
\text { placebo-controlle } \\
\text { trial }\end{array}$ & $\begin{array}{l}25 \mu \mathrm{g} 17 \beta \text {-estradiol } \\
\left(\text { Vagifem }^{\star}\right) \text { or } \\
\text { placebo } \\
12 \text { weeks }\end{array}$ & $\begin{array}{l}\mathrm{n}=164 \\
(10 \text { withdrew }) \\
45-70 \\
\text { a }\end{array}$ & $\begin{array}{l}\text { Vaginal symptoms } \\
\text { related to } \\
\text { vaginal atrophy } \\
3\end{array}$ & $\begin{array}{l}2 \mathrm{a} \\
\text { Presence of external } \\
\text { dyspareunia, rating of mild, } \\
\text { moderate or severe }\end{array}$ & $\begin{array}{l}\text { Treatment significantly } \\
\text { improved dyspareunia } \\
\text { compared with placebo; } \\
\text { moderate to severe } \\
\text { dyspareunia before } \\
\text { treatment: HRT } 42.5 \% \text {, } \\
\text { placebo } 45.8 \% \text {; moderate } \\
\text { to severe dyspareunia } \\
\text { post-treatment: HRT } 8.0 \% \text {, } \\
\text { placebo } 24.4 \%\end{array}$ & Short treatment duration \\
\hline $\begin{array}{l}\text { Henriksson et al, } \\
1994 \text { (82) } \\
\text { Open-label, } \\
\text { randomized, } \\
\text { parallel group } \\
\text { trial }\end{array}$ & $\begin{array}{l}2 \text { mg } 17 \beta \text {-estradiol } \\
\text { vaginal ring } \\
\left(\text { Estring }^{\dagger}\right) \text { or } \\
0.5 \text { mg estriol } \\
\text { pessary } \\
\left.\text { (Ovestin }{ }^{\ddagger}\right) \\
12 \text { weeks }\end{array}$ & $\begin{array}{l}\mathrm{n}=165 \\
\text { (8 withdrew) } \\
\text { Ring, } \\
59.5 \pm 6.5 \\
\text { pessary, } \\
59.8 \pm 7.2 \\
\text { a }\end{array}$ & $\begin{array}{l}\text { Signs and } \\
\text { symptoms of } \\
\text { vaginal atrophy } \\
3 a, 3 b\end{array}$ & $\begin{array}{l}2 a \\
\text { Presence of mild, moderate } \\
\quad \text { or severe dyspareunia }\end{array}$ & $\begin{array}{l}\text { Both treatments similarly } \\
\text { improved dyspareunia; } \\
\text { ring: response rate } 93 \% \text {, } \\
\text { cure rate } 75 \% \text {; pessary: } \\
\text { response rate } 100 \% \text {, cure } \\
\text { rate } 75 \%\end{array}$ & $\begin{array}{l}\text { Short treatment duration; } \\
\text { investigators not } \\
\text { blinded to participant } \\
\text { group membership; did } \\
\text { not report rate of } \\
\text { dyspareunia in sexually } \\
\text { inactive women }\end{array}$ \\
\hline $\begin{array}{l}\text { Ayton et al, } \\
1996 \text { (83) } \\
\text { Open-label, } \\
\text { randomized, } \\
\text { parallel group } \\
\text { trial }\end{array}$ & $\begin{array}{l}2 \text { mg } 17 \beta \text {-estradiol } \\
\text { vaginal ring } \\
\left.\text { (Estring }^{\dagger}\right) \text { or } \\
0.625 \mathrm{mg} \\
\text { conjugated equine } \\
\text { estrogen cream } \\
12 \text { weeks }\end{array}$ & $\begin{array}{l}\mathrm{n}=194 \\
(18 \text { withdrew }) \\
\text { Ring, } \\
59.3 \pm 7.3 \\
\text { cream, } \\
59.9 \pm 7.3 \\
\text { a }\end{array}$ & $\begin{array}{l}\text { Signs and } \\
\text { symptoms of } \\
\text { vaginal atrophy } \\
3 a\end{array}$ & $\begin{array}{l}2 a \\
\text { Presence of mild, moderate } \\
\quad \text { or severe dyspareunia }\end{array}$ & $\begin{array}{l}\text { Both treatments similarly } \\
\text { improved dyspareunia; } \\
\text { ring: response rate } \sim 75 \% \text {, } \\
\text { cure rate } \sim 68 \% \text {; cream: } \\
\text { response rate } \sim 77 \% \text {, cure } \\
\text { rate } \sim 57 \%\end{array}$ & $\begin{array}{l}\text { Reported results } \\
\text { presented on a bar } \\
\text { chart without specific } \\
\text { numbers, which was } \\
\text { difficult to read; short } \\
\text { treatment duration }\end{array}$ \\
\hline $\begin{array}{l}\text { Barentsen et al, } \\
1997 \text { (84) } \\
\text { Single-blind, } \\
\text { open-label, } \\
\text { randomized, } \\
\text { parallel group } \\
\text { crossover trial }\end{array}$ & $\begin{array}{l}2 \text { mg } 17 \beta \text {-estradiol } \\
\text { vaginal ring } \\
\left.\text { (Estring }^{\dagger}\right) \text { or } \\
0.5 \mathrm{mg} \text { estriol } \\
\text { cream } \\
12 \text { weeks }\end{array}$ & $\begin{array}{l}\mathrm{n}=165 \\
57.9 / 58.5 \\
?\end{array}$ & $\begin{array}{l}\text { Signs and } \\
\text { symptoms of } \\
\text { vaginal atrophy } \\
3 a, 3 b\end{array}$ & $\begin{array}{l}2 a \\
\text { Presence of mild, moderate } \\
\text { or severe dyspareunia }\end{array}$ & $\begin{array}{l}\text { Both treatments similarly } \\
\text { improved dyspareunia; } \\
\text { response rate } 90 \% \text {, cure } \\
\text { rate } 65 \%\end{array}$ & $\begin{array}{l}\text { Short treatment duration; } \\
\text { did not report baseline } \\
\text { rates of dyspareunia }\end{array}$ \\
\hline $\begin{array}{l}\text { Chompootaweep } \\
\text { et al, } 1998(95) \\
\text { Randomized, } \\
\text { parallel group } \\
\text { trial }\end{array}$ & $\begin{array}{l}250 \mu \mathrm{g} \\
\text { levonorgestrel } \\
\text { and } 30 \mu \mathrm{g} \text { ethinyl } \\
\text { estradiol or } \\
0.625 \mathrm{mg}\end{array}$ & $\begin{array}{l}\mathrm{n}=40 \\
54.45 \\
?\end{array}$ & $\begin{array}{l}\text { Symptoms } \\
\text { of vaginal } \\
\text { atrophy } \\
3\end{array}$ & $\begin{array}{l}3 \mathrm{~b} \\
\text { Presence of mild, } \\
\text { moderate, severe or no } \\
\text { dyspareunia }\end{array}$ & $\begin{array}{l}\text { Dyspareunia resolved } \\
\text { over duration of treatment } \\
\text { in both treatment groups }\end{array}$ & $\begin{array}{l}\text { Short treatment duration; } \\
\text { investigators not } \\
\text { blinded to participant } \\
\text { group membership; } \\
\text { small n }\end{array}$ \\
\hline
\end{tabular}

estrogen cream

8 weeks

\begin{tabular}{|c|c|c|c|c|}
\hline $\begin{array}{l}\text { Casper and Petri, } \\
1999 \text { (31) } \\
\text { Double-blind, } \\
\text { randomized, } \\
\text { placebo- } \\
\text { controlled trial }\end{array}$ & $\begin{array}{l}2 \text { mg } 17 \beta \text {-estradiol } \\
\text { vaginal ring } \\
\left(\text { Estring }^{\dagger}\right) \text { or } \\
\text { placebo } \\
24 \text { weeks }\end{array}$ & $\begin{array}{l}\mathrm{n}=84 \\
(13 \text { withdrew }) \\
? \\
?\end{array}$ & $\begin{array}{l}\text { Signs and } \\
\text { symptoms of } \\
\text { vaginal atrophy } \\
3 a, 3 b\end{array}$ & $\begin{array}{l}\text { ? } \\
\text { Possibly a yes/no question, } \\
\text { not clear }\end{array}$ \\
\hline $\begin{array}{l}\text { Dugal et al, } \\
2000 \text { (96) } \\
\text { Single-blind, } \\
\text { randomized, } \\
\text { parallel group trial }\end{array}$ & $\begin{array}{l}25 \mu \mathrm{g} 17 \beta \text {-estradiol } \\
\left(\text { Vagifem }^{\star}\right) \text { or } \\
0.5 \text { mg estriol } \\
\text { vagitory } \\
24 \text { weeks }\end{array}$ & $\begin{array}{l}\mathrm{n}=96 \\
(11 \text { withdrew }) \\
58.75,50-70 \\
?\end{array}$ & $\begin{array}{l}\text { Signs and } \\
\text { symptoms of } \\
\text { vaginal atrophy } \\
3\end{array}$ & $\begin{array}{l}2 a \\
\text { Self-report using visual } \\
\text { analogue scale ranging from } \\
\text { none to extreme }\end{array}$ \\
\hline $\begin{array}{l}\text { Lose and Englev, } \\
2000 \text { (85) } \\
\text { Randomized, } \\
\text { parallel group } \\
\text { trial }\end{array}$ & $\begin{array}{l}2 \text { mg } 17 \beta \text {-estradiol } \\
\text { vaginal ring } \\
\left(\text { Estring }^{\dagger}\right) \text { or } \\
0.5 \mathrm{mg} \text { estriol } \\
\left.\text { pessary (Ovestin }{ }^{\ddagger}\right) \\
12 \text { weeks }\end{array}$ & $\begin{array}{l}\mathrm{n}=254 \\
(3 \text { withdrew) } \\
66 \\
?\end{array}$ & $\begin{array}{l}\text { One sign of } \\
\text { vaginal atrophy } \\
3 a, 3 b\end{array}$ & $\begin{array}{l}2 \mathrm{a} \\
\text { Possibly a yes/no question, } \\
\text { not clear }\end{array}$ \\
\hline
\end{tabular}

Treatment significantly improved dyspareunia compared with placebo; dyspareunia relief posttreatment: HRT 90\%, placebo $45 \%$

Dyspareunia significantly improved for both treatment groups over the course of the trial

Both treatments similarly improved dyspareunia: ring: response rate $75 \%$, cure rate $61 \%$; pessary: response rate $78 \%$, cure rate $71 \%$
Short treatment duration did not report baseline rates of dyspareunia; no reporting of participant age, recruitment method, or measurements used

Short treatment duration did not report baseline rates of dyspareunia

Continued on next page 
TABLE 5 CONTINUED

Effect of recommended estrogen supplementations on dyspareunia in postmenopausal women

\begin{tabular}{|c|c|c|c|c|c|c|}
\hline Study & HRT & $\begin{array}{l}\text { Subjects, } \\
\text { age (years), } \\
\text { recruitment }\end{array}$ & $\begin{array}{l}\text { Inclusion } \\
\text { criteria, } \\
\text { reproductive } \\
\text { phases }\end{array}$ & $\begin{array}{l}\text { Measurement of } \\
\text { dyspareunia, } \\
\text { administration }\end{array}$ & $\begin{array}{l}\text { Dyspareunia } \\
\text { results }\end{array}$ & $\begin{array}{l}\text { Methodological } \\
\text { problems }\end{array}$ \\
\hline $\begin{array}{l}\text { Simunic et al, } \\
2003(32) \\
\text { Double-blind, } \\
\text { randomized, } \\
\text { placebo- } \\
\text { controlled trial }\end{array}$ & $\begin{array}{l}25 \mu \mathrm{g} 17 \beta \text {-estradiol } \\
\left(\text { Vagifem }{ }^{\star}\right) \text { or } \\
\text { placebo } \\
12 \text { months }\end{array}$ & $\begin{array}{l}\mathrm{n}=1612 \\
\text { HRT }=828 \\
\text { Placebo=784 } \\
\text { HRT } 58.1 \pm 6.9 \\
\text { Placebo } \\
59.5 \pm 7.1 \\
\text { a }\end{array}$ & $\begin{array}{l}\text { Symptoms of } \\
\text { vaginal atrophy } \\
3 a\end{array}$ & $\begin{array}{l}2 \mathrm{a} \\
\text { Possibly a yes/no question, } \\
\text { not clear }\end{array}$ & $\begin{array}{l}\text { Treatment significantly } \\
\text { improved dyspareunia } \\
\text { compared with placebo; } \\
\text { dyspareunia before } \\
\text { treatment: HRT } 46.1 \% \text {, } \\
\text { placebo } 40.6 \% \text {; } \\
\text { dyspareunia post-treatment } \\
\text { HRT } 12.4 \% \text {, placebo } 29.7 \%\end{array}$ & \\
\hline $\begin{array}{l}\text { Long et al, } \\
2006 \text { (86) } \\
\text { Randomized, } \\
\text { parallel group } \\
\text { trial }\end{array}$ & $\begin{array}{l}0.625 \mathrm{mg} \\
\text { conjugated } \\
\text { equine estrogen } \\
\text { oral pill or } \\
0.625 \mathrm{mg} \\
\text { conjugated equine } \\
\text { estrogen cream } \\
24 \text { weeks }\end{array}$ & $\begin{array}{l}\mathrm{n}=73 \\
(16 \text { withdrew) } \\
\text { Oral, } \\
53.3 \pm 6.2 \\
\text { cream, } \\
54.3 \pm 7.3 \\
\text { a }\end{array}$ & $\begin{array}{l}\text { Previous } \\
\text { hysterectomy } \\
3 \mathrm{~b}\end{array}$ & $\begin{array}{l}2 a \\
\text { Presence of dyspareunia, } \\
\text { rating of "all the time", "most } \\
\text { of the time", "little of the } \\
\text { time", "none of the time" }\end{array}$ & $\begin{array}{l}\text { Topical treatment, but not } \\
\text { oral administration, } \\
\text { significantly improved } \\
\text { dyspareunia; dyspareunia } \\
\text { most or all of the time } \\
\text { before treatment: topical } \\
66.71 \% \text {, oral } 63 \% \text {; } \\
\text { dyspareunia most or all of } \\
\text { the time post-treatment: } \\
\text { topical } 20 \% \text {, oral } 33.3 \%\end{array}$ & $\begin{array}{l}\text { Did not report rate of } \\
\text { dyspareunia in sexually } \\
\text { inactive women within } \\
\text { the previous month; } \\
\text { treatment duration; } \\
\text { investigators not } \\
\text { blinded to participant } \\
\text { group membership }\end{array}$ \\
\hline
\end{tabular}

Age presented as mean $\pm S D$ and/or range. Recruitment: a Gynelogical outpatients, ? Not specified/not clear; Reproductive phases: 3 Postmenopausal, 3a Naturally postmenopausal specified, 3b Surgically postmenopausal specified; Measures of dyspareunia: 2 Adhoc structured questionnaire or interview, 3 Diary or calendar (self-report); ? Not specified/not clear; Administration: a Face-to-face, b Self-administered at home. *Novo Nordisk Inc, USA; †Pfizer Inc, USA; ¥Organon Inc, USA. HRT Hormone replacement therapy

benefited is not known. A considerable portion of dyspareunia cases were resistant to hormonal treatment. It is possible that longer treatment durations may have produced better response rates, given that restoration of vaginal tissue function may require 18 to 24 months of estrogen therapy (90). Notwithstanding, between $10 \%$ and $27 \%$ of dyspareunia sufferers in the most methodologically sound investigations did not improve $(31,32,81)$.

\section{CONCLUSIONS AND FUTURE DIRECTIONS}

The present review found evidence that dyspareunia is a common problem in postmenopausal women, frequently related to declining estrogen levels. This is supported by longitudinal and cross-sectional data $(59,60)$. Furthermore, treatment outcome studies of recommended forms of local estrogen administration have demonstrated that they are effective at relieving dyspareunia in most postmenopausal women who have vaginal atrophy $(70,73,74)$. A substantial amount of evidence, however, has been found to suggest that estrogen decline is unlikely to be the sole cause of dyspareunia in postmenopausal women (eg, 61-63). Moreover, a considerable proportion of postmenopausal dyspareunia sufferers with concurrent vaginal atrophy did not benefit from estrogen supplementation $(32,81,82,85)$, and placebo effects seem to be quite strong $(31,32,81)$. Presently, there is a lack of research about factors other than estrogen that may be associated with the development of dyspareunia in postmenopausal women, which may be a result of the current reductionist conceptualization of postmenopausal dyspareunia.

Past work from our multidisciplinary research group has initiated a change in perspective towards conceptualizing dyspareunia as a multidimensional pain syndrome $(44,91,92)$. In envisaging dyspareunia within a multiaxial pain syndrome framework, researchers have been guided toward using pain methodology to investigate this condition and its treatment in premenopausal women. This change in approach has had important scientific and clinical implications. For example, we have demonstrated that pain characteristics such as location, temporal pattern, intensity and sensory quality are useful diagnostic criteria to discriminate subtypes of premenopausal dyspareunic pain (44). Furthermore, similar to other chronic pain syndromes (eg, headaches, lower back pain), it has been found that multiple mediating factors contribute to, exacerbate and maintain dyspareunia in premenopausal women; these factors need to be addressed in treatment (eg, 91,93). Indeed, dyspareunia is now classified as a form of chronic pain by the International Association for the Study of Pain (45).

While this paradigm shift has impacted research and treatment of dyspareunic pain syndromes in premenopausal women, it has yet to be extended to analogous pain affecting postmenopausal women. A reconceptualization of postmenopausal dyspareunia as a pain disorder is overdue, which is reflected by the lack of literature concerning dyspareunia. This change in perspective would suggest that the chief symptom, pain, is a function of multiple biological, psychological and interpersonal factors. Similar to other forms of chronic pain, a single etiological mechanism (such as estrogen levels) is unlikely to account for the development and maintenance of all forms of dyspareunic pain in postmenopausal women.

SUPPORT: This work was supported by a grant from the Canadian Institutes of Health Research and fellowships from Fonds pour la Formation de Chercheurs et l'Aide a la Recherche Québec, Fonds de la Recherche en Santé Québec and the Research Institute of the McGill University Health Centre.

ACKNOWLEDGEMENTS: The authors thank Seth Davis, Melissa A Farmer, Nicole Flory, Tuuli Kukkonen, Marie-Andrée Lahaie, Louise Overington, Laurel Paterson, Kim Payne and Caroline Pukall for their thoughtful comments on earlier drafts of this manuscript. 


\section{REFERENCES}

1. Easley, ED. Sex problems after the menopause. Clin Obstet Gynecol 1978;21:269-77.

2. Studd JWW, Watson NR, Henderson A. Symptoms and metabolic sequelae of the menopause. In: Drife JO, Studd JWW, eds. HRT and Osteoporosis. London: Springer Verlag, 1990:23-34.

3. Meana M, Binik YM, Khalifé S, Cohen DR. Biopsychosocial profile of women with dyspareunia. Obstet Gynecol 1997;90:583-9.

4. Channon LD, Ballinger SE. Some aspects of sexuality and vaginal symptoms during the menopause and their relation to anxiety and depression. Br J Med Psychol 1986;59:173-80.

5. Bachmann $\mathrm{G}$. The estriadol vaginal ring - a study of existing clinical data. Maturitas 1995;22(Suppl):S21-9.

6. Oldenhave A, Jaszmann LJ, Haspels AA, Everaerd WT. Impact of climacteric on well-being. A survey based on 5213 women 39 to 60 years old. Am J Obstet Gynecol 1993;168:772-80.

7. Goldstein I, Alexander JL. Practical aspects in the management of vaginal atrophy and sexual dysfunction in perimenopausal and postmenopausal women. J Sex Med 2005;2(Suppl 3):154-65.

8. Pandit L, Ouslander JG. Postmenopausal vaginal atrophy and atrophic vaginitis. Am J Med Sci 1997;314:228-31.

9. Sarrel PM. Sexuality and menopause. Obstet Gynecol 1990;75(4 Suppl):26S-30S.

10. Hagstad A. Gynecology and sexuality in middle-aged women. Women Health 1988;13:57-80.

11. Osborn M, Hawton K, Gath D. Sexual dysfunction among middle aged women in the community. Br Med J (Clin Res Ed) 1988;296:959-62.

12. Bachmann GA, Leiblum SR, Grill J. Brief sexual inquiry in gynecologic practice. Obstet Gynecol 1989;73:425-7.

13. Laumann EO, Gagnon JH, Michael RT, Michaels S. The Social Organization of Sexuality: Sexual Practices in the United States. Chicago: University of Chicago Press, 1994.

14. Najman JM, Dunne MP, Boyle FM, Cook MD, Purdie DM. Sexual dysfunction in the Australian population. Aust Fam Physician 2003;32:951-4

15. Nicolosi A, Laumann EO, Glasser DB, Moreira ED Jr, Paik A, Gingell C; Global Study of Sexual Attitudes and Behaviors Investigators' Group. Sexual behavior and sexual dysfunctions after age 40: The global study of sexual attitudes and behaviors. Urology 2004;64:991-7.

16. World Health Organization Scientific Group. Research on the menopause. World Health Organ Tech Rep Ser 1981;670:1-120.

17. Sukwatana P, Meekhangvan J, Tamrongterakul T, Tanapat Y, Asavarait S, Boonjitrpimon P. Menopausal symptoms among Thai women in Bangkok. Maturitas 1991;13:217-28.

18. Rekers H, Drogendijk AC, Valkenburg HA, Riphagen F. The menopause, urinary incontinence and other symptoms of the genito-urinary tract. Maturitas 1992;15:101-11.

19. Líndal E, Stefànsson JG. The lifetime prevalence of psychosexual dysfunction among 55- to 57-year-olds in Iceland. Soc Psychiatry Psychiatr Epidemiol 1993;28:91-5.

20. Sarrel PM, Whitehead MI. Sex and menopause: Defining the issues. Maturitas 1985;7:217-24.

21. Dhillon HK, Singh HJ, Ghaffar NA. Sexual function in menopausal women in Kelantan, Malaysia. Maturitas 2005;52:256-63.

22. Barlow DH, Cardozo LD, Francis RM, et al. Urogenital ageing and its effect on sexual health in older British women. Br J Obstet Gynecol 1997;104:87-91.

23. Barlow DH, Samsioe G, van Geelen JM. A study of European womens' experience of the problems of urogenital ageing and its management. Maturitas 1997;27:239-47.

24. Borissova AM, Kovatcheva R, Shinkov A, Vukov M. A study of the psychological status and sexuality in middle-aged Bulgarian women: Significance of the hormone replacement therapy (HRT). Maturitas 2001;39:177-83.

25. Ballinger SE. Psychosocial stress and symptoms of menopause: A comparative study of menopause clinic patients and nonpatients. Maturitas 1985;7:315-27.

26. Rosen RC, Taylor JF, Leiblum SR, Bachmann GA. Prevalence of sexual dysfunction in women: Results of a survey study of 329 women in an outpatient gynecological clinic. J Sex Marital Ther 1993;19:171-88.

27. Versi E, Harvey MA, Cardozo L, Brincat M, Studd JW. Urogenital prolapse and atrophy at menopause: A prevalence study. Int Urogynecol J Pelvic Floor Dysfunct 2001;12:107-10.
28. Flory N, Bissonnette F, Binik YM. Psychosocial effects of hysterectomy: Literature review. J Psychosom Res 2005;59:117-29.

29. Rhodes JC, Kjerulff KH, Langenberg PW, Guzinski GM. Hysterectomy and sexual functioning. JAMA 1999;282:1934-41.

30. Zussman L, Zussman S, Sunley R, Bjornson E. Sexual response after hysterectomy-oophorectomy: Recent studies and reconsideration of psychogenesis. Am J Obstet Gynecol 1981;140:725-9.

31. Casper F, Petri E. Local treatment of urogenital atrophy with an estradiol-releasing vaginal ring: A comparative and a placebocontrolled multicenter study. Vaginal Ring Study Group. Int Urogynecol J Pelvic Floor Dysfunct 1999;10:171-6.

32. Simunic V, Banovic I, Ciglar S, Jeren L, Pavicic Baldani D, Sprem M. Local estrogen treatment in patients with urogenital symptoms. Int J Gynaecol Obstet 2003;82:187-97.

33. Melzack R. The McGill Pain Questionnaire: Major properties and scoring methods. Pain 1975;1:277-99.

34. McCoy NL. The McCoy Female Sexuality Questionnaire. Qual Life Res 2000;9(Suppl 1):739-45.

35. Rosen R, Brown C, Heiman J, et al. The Female Sexual Function Index (FSFI): A multidimensional self-report instrument for the assessment of female sexual function. J Sex Marital Ther 2000;26:191-208.

36. Iosif CS, Bekassy Z. Prevalence of genito-urinary symptoms in the late menopause. Acta Obstet Gynecol Scand 1984;63:257-60.

37. Berg G, Gottwall T, Hammar M, Lindgren R. Climacteric symptoms among women aged 60-62 in Linköping, Sweden, in 1986. Maturitas 1988;10:193-9.

38. Moore B, Kombe H. Climacteric symptoms in a Tanzanian community. Maturitas 1991;13:229-34

39. Dennerstein L, Dudley EC, Hopper JL, Burger H. Sexuality, hormones and the menopausal transition. Maturitas 1997;26:83-93.

40. van Geelen JM, van de Weijer PH, Arnolds HT. Urogenital symptoms and the resulting discomfort in non-institutionalized Dutch women aged 50-75 years. Int Urogynecol J Pelvic Floor Dysfunct 2000;11:9-14.

41. Maartens LW, Leusink GL, Knottnerus JA, Smeets CG, Pop VJ. Climacteric complaints in the community. Fam Pract 2001;18:189-94.

42. Cain VS, Johannes CB, Avis NE, et al. Sexual functioning and practices in a multi-ethnic study of midlife women: Baseline results from SWAN. J Sex Res 2003;40:266-76.

43. Oskay UY, Beji NK, Yalcin O. A study on urogenital complaints of postmenopausal women aged 50 and over. Acta Obstet Gynecol Scand 2005;84:72-8

44. Meana M, Binik YM, Khalifé S, Cohen D. Dyspareunia: Sexual dysfunction or pain syndrome? J Nerv Ment Dis 1997;185:561-9.

45. Merskey H, Bogduk N, eds. Classification of Chronic Pain: Descriptions of Chronic Pain Syndromes and Definitions of Pain Terms, 2nd edn. Washington: IASP Press, 1994.

46. Moyal-Barracco M, Lynch PJ. 2003 ISSVD terminology and classification of vulvodynia: A historical perspective. J Reprod Med 2004:49:772-7.

47. Binik YM, Meana M, Berkley K, Khalifé S. The sexual pain disorders: Is the pain sexual or is the sex painful? Annu Rev Sex Res 1999;10:210-35.

48. Harlow BL, Wise LA, Stewart EG. Prevalence and predictors of chronic lower genital tract discomfort. Am J Obstet Gynecol 2001;185:545-50.

49. Kao A, Binik YM, Khalifé S, Amsel R. Vulvar vestibulitis syndrome after menopause? If the criteria fit... Poster presentation, 33rd annual meeting of the International Academy of Sex Research. Vancouver, 2007.

50. Babula O, Lazdane G, Kroica J, Linhares IM, Ledger WJ, Witkin SS. Frequency of interleukin-4 (IL-4) - 589 gene polymorphism and vaginal concentrations of IL-4, nitric oxide, and mannose-binding lectin in women with recurrent vulvovaginal candidiasis. Clin Infect Dis 2005;40:1258-62.

51. Payne KA, Binik YM, Amsel R, Khalifé S. When sex hurts, anxiety and fear orient attention towards pain. Eur J Pain 2005;9:427-36.

52. Basson R. Recent advances in women's sexual function and dysfunction. Menopause 2004;11:714-25.

53. Oldenhave A. Some aspects of sexuality during the normal climacteric. In: Berg G, Hammer M, eds. The Modern Management of the Menopause: A Perspective for the 21st Century. London: Parthenon, 1994:605-15. 
54. Hayes R, Dennerstein L. The impact of aging on sexual function and sexual dysfunction in women: A review of population-based studies. J Sex Med 2005;2:317-30.

55. Laumann EO, Paik A, Rosen RC. Sexual dysfunction in the United States: Prevalence and predictors. JAMA 1999;281:537-44

56. Weber AM, Walters MD, Schover LR, Mitchinson A. Vaginal anatomy and sexual function. Obstet Gynecol 1995;86:946-9.

57. Mishra G, Kuh D. Sexual functioning throughout menopause: The perceptions of women in a British cohort. Menopause 2006; 13:880-90.

58. Dennerstein L, Dudley E, Burger H. Are changes in sexual functioning during midlife due to aging or menopause? Fertil Steril 2001;76:456-60.

59. Dennerstein L, Lehert P, Burger H. The relative effects of hormones and relationship factors on sexual function of women through the natural menopausal transition. Fertil Steril 2005;84:174-80.

60. Avis NE, Stellato R, Crawford S, Johannes C, Longcope C. Is there an association between menopause status and sexual functioning? Menopause 2000;7:297-309.

61. James CE, Breeson AJ, Kovacs G, et al. The symptomatology of the climacteric in relation to hormonal and cytological factors. Br J Obstet Gynaecol 1984;91:56-62.

62. Cutler WB, Garcia CR, McCoy N. Perimenopausal sexuality. Arch Sex Behav 1987;16:225-34

63. Laan E, van Lunsen RH. Hormones and sexuality in postmenopausal women: A psychophysiological study. J Psychosom Obstet Gynaecol 1997;18:126-33.

64. Bachmann GA, Leiblum SR. The impact of hormones on menopausal sexuality: A literature review. Menopause 2004;11:120-30.

65. Gürel H, Gürel SA. Pelvic relaxation and associated risk factors: The results of logistic regression analysis. Acta Obstet Gynecol Scand 1999;78:290-3.

66. Reay Jones NH, Healy JC, King LJ, Saini S, Shousha S, Allen-Mersh TG Pelvic connective tissue resilience decreases with vaginal delivery, menopause and uterine prolapse. Br J Surg 2003;90:466-72.

67. Rosenbaum TY. Managing postmenopausal dyspareunia: Beyond hormone therapy.

<http://www.femalepatient.com/html/arc/sig/sexu/articles/031_11_0 24.asp> (Version current at May 29, 2008).

68. Goldstein I. Current management strategies of the postmenopausal patient with sexual health problems. J Sex Med 2007;4(Suppl 3):235-53.

69. Reissing ED, Brown C, Lord MJ, Binik YM, Khalifé S. Pelvic floor muscle functioning in women with vulvar vestibulitis syndrome. J Psychosom Obstet Gynaecol 2005;26:107-13.

70. Johnston SL, Farrell SA, Bouchard C, et al; SOGC Joint Committee-Clinical Practice Gynaecology and Urogynaecology. The detection and management of vaginal atrophy. J Obstet Gynaecol Can 2004;26:503-15.

71. Bygdeman M, Swahn ML. Replens versus dienoestrol cream in the symptomatic treatment of vaginal atrophy in postmenopausal women. Maturitas 1996;23:259-63.

72. Sarrel PM. Effects of hormone replacement therapy on sexual psychophysiology and behavior in postmenopause. J Womens Health Gend Based Med 2000:9(Suppl 1):S25-32.

73. North American Menopause Society. The role of local vaginal estrogen for treatment of vaginal atrophy in postmenopausal women: 2007 position statement of The North American Menopause Society. Menopause 2007;14:355-69.

74. Suckling J, Lethaby A, Kennedy R. Local oestrogen for vaginal atrophy in postmenopausal women. Cochrane Database Syst Rev 2006; (4):CD001500.

75. Myers LS, Dixen J, Morrissette D, Carmichael M, Davidson JM. Effects of estrogen, androgen, and progestin on sexual psychophysiology and behavior in postmenopausal women. J Clin Endocrinol Metab 1990;70:1124-31.

76. Nathorst-Böös J, Wiklund I, Mattsson L-A, Sandin K, von Schoultz B. Is sexual life influenced by transdermal estrogen therapy? A double blind placebo controlled study in postmenopausal women. Acta Obstet Gynecol Scand 1993;72:656-60.

77. Morris EP, Wilson POG, Robinson J, Rymer JM. Long term effects of tibolone on the genital tract in postmenopausal women. $\mathrm{Br} \mathrm{J}$ Obstet Gynaecol 1999;106:954-9.
78. Castelo-Branco C, Vicente JJ, Figueras F, et al. Comparative effects of estrogens plus androgens and tibolone on bone, lipid pattern and sexuality in postmenopausal women. Maturitas 2000;34:161-8.

79. Flöter A, Nathorst-Böös J, Carlström K, von Schoultz B. Addition of testosterone to estrogen replacement therapy in oophorectomized women: Effects on sexuality and well-being. Climacteric 2002;5:357-65.

80. Fonseca AM, Bagnoli VR, Penteado SR, Paixão JS, Cavalcanti AL, Pinotti JA. Monophasic estrogen-progestogen therapy and sexuality in postmenopausal women. Clin Drug Investig 2007;27:131-7.

81. Eriksen PS, Rasmussen H. Low-dose 17 beta-estradiol vaginal tablets in the treatment of atrophic vaginitis: A double-blind placebo controlled study. Eur J Obstet Gynecol Reprod Biol 1992;44:137-44.

82. Henriksson L, Stjernquist M, Boquist L, Alander U, Selinus I. A comparative multicenter study of the effects of continuous lowdose estradiol released from a new vaginal ring versus estriol vaginal pessaries in postmenopausal women with symptoms and signs of urogenital atrophy. Am J Obstet Gynecol 1994;171:624-32.

83. Ayton RA, Darling GM, Murkies AL, et al. A comparative study of safety and efficacy of continuous low dose oestradiol released from a vaginal ring compared with conjugated equine oestrogen vaginal cream in the treatment of postmenopausal urogenital atrophy. Br J Obstet Gynaecol 1996;103:351-8

84. Barentsen R, van de Weijer PH, Schram JH. Continuous low dose estradiol released from a vaginal ring versus estriol vaginal cream for urogenital atrophy. Eur J Obstet Gynecol Reprod Biol 1997;71:73-80.

85. Lose $G$, Englev E. Oestradiol-releasing vaginal ring versus oestriol vaginal pessaries in the treatment of bothersome lower urinary tract symptoms. BJOG 2000;107:1029-34.

86. Long CY, Liu CM, Hsu SC, Wu CH, Wang CL, Tsai EM. A randomized comparative study of the effects of oral and topical estrogen therapy on the vaginal vascularization and sexual function in hysterectomized postmenopausal women. Menopause 2006;13:737-43.

87. Alexander JL, Kotz K, Dennerstein L, Kutner SJ, Wallen K, Notelovitz M. The effects of postmenopausal hormone therapies on female sexual functioning: A review of double-blind, randomized controlled trials. Menopause 2004;11:749-65.

88. Ballagh SA. Vaginal hormone therapy for urogenital and menopausal symptoms. Semin Reprod Med 2005;23:126-40.

89. Leiblum S, Bachmann G, Kemmann E, Colburn D, Swartzman L. Vaginal atrophy in the postmenopausal woman. The importance of sexual activity and hormones. JAMA 1983;249:2195-8.

90. Semmens JP, Tsai CC, Semmens EC, Loadholt CB. Effects of estrogen therapy on vaginal physiology during menopause. Obstet Gynecol 1985;66:15-8.

91. Pukall CF, Reissing ED, Binik YM, Khalifé S, Abbott FV. New clinical and research perspectives on the sexual pain disorders. J Sex Educ Ther 2000;25:36-44

92. Reissing ED, Binik YM, Khalifé S, Cohen D, Amsel R. Etiological correlates of vaginismus: Sexual and physical abuse, sexual knowledge, sexual self-schema, and relationship adjustment. J Sex Marital Ther 2003;29:47-59.

93. Bergeron S, Binik YM, Khalifé S, et al. A randomized comparison of group cognitive-behavioral therapy, surface electromyographic biofeedback, and vestibulectomy in the treatment of dyspareunia resulting from vulvar vestibulitis. Pain 2001;91:297-306

94. Castelo-Branco C, Palacios S, Mostajo D, Tobar C, von Helde S. Menopausal transition in Movima women, a Bolivian NativeAmerican. Maturitas 2005;51:380-5.

95. Chompootaweep S, Nunthapisud P, Trivijitsilp P, Sentrakul P, Dusitsin N. The use of two estrogen preparations (a combined contraceptive pill versus conjugated estrogen cream) intravaginally to treat urogenital symptoms in postmenopausal Thai women: A comparative study. Clin Pharmacol Ther 1998;64:204-10.

96. Dugal R, Hesla K, Sørdal T, Aase KH, Lilleeidet O, Wickstrøm E. Comparison of usefulness of estradiol vaginal tablets and estriol vagitories for treatment of vaginal atrophy. Acta Obstet Gynecol Scand 2000;79:293-7. 


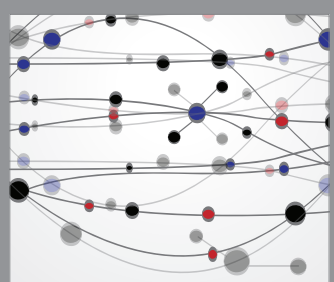

The Scientific World Journal
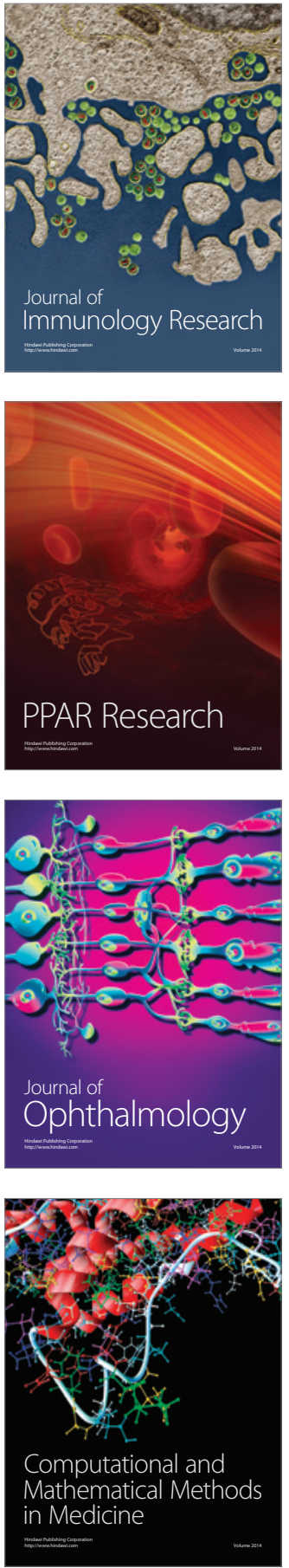

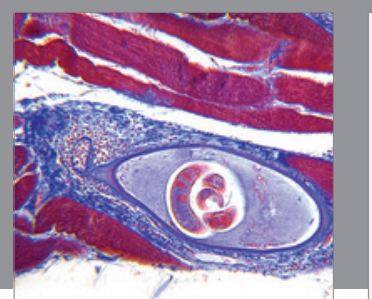

Gastroenterology Research and Practice

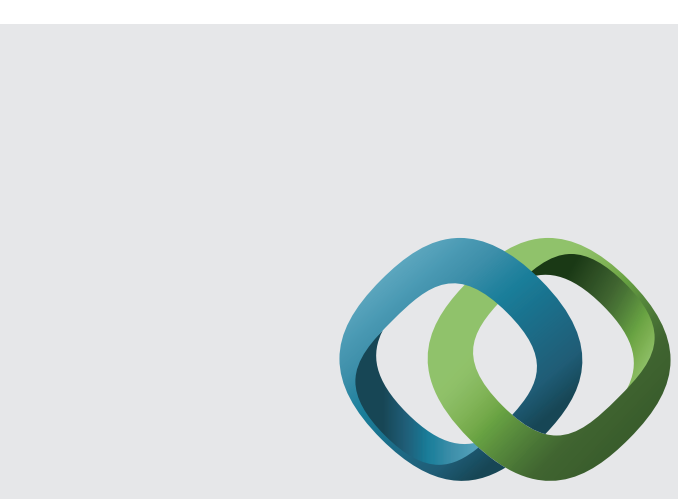

\section{Hindawi}

Submit your manuscripts at

http://www.hindawi.com
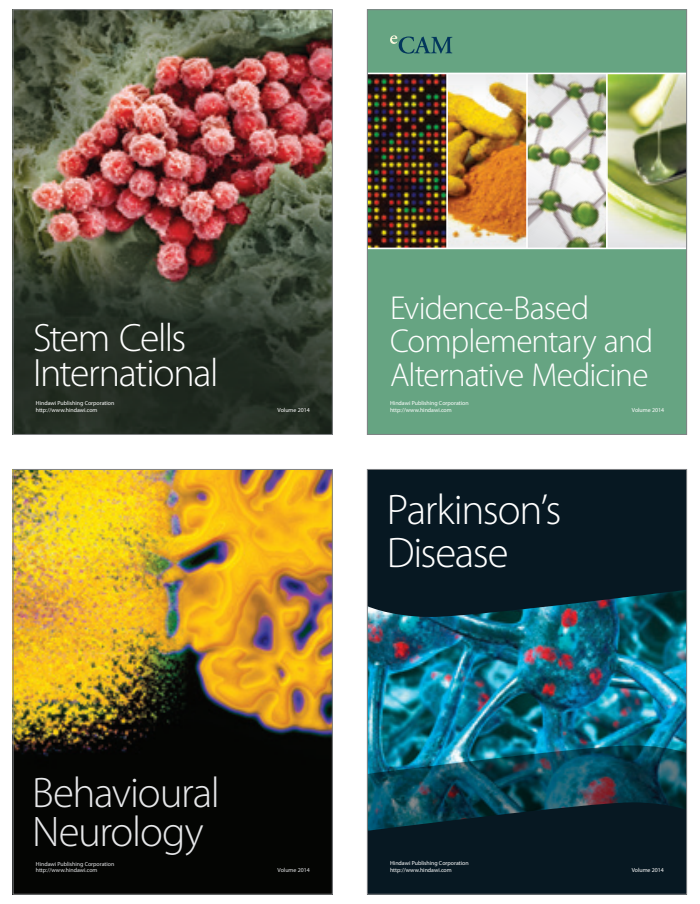
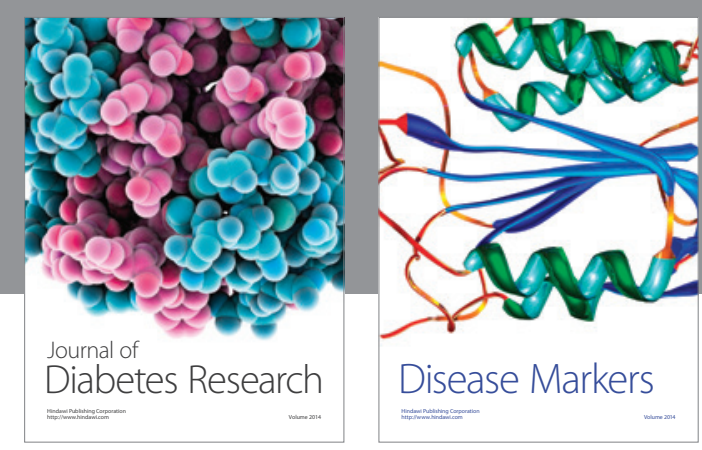

Disease Markers
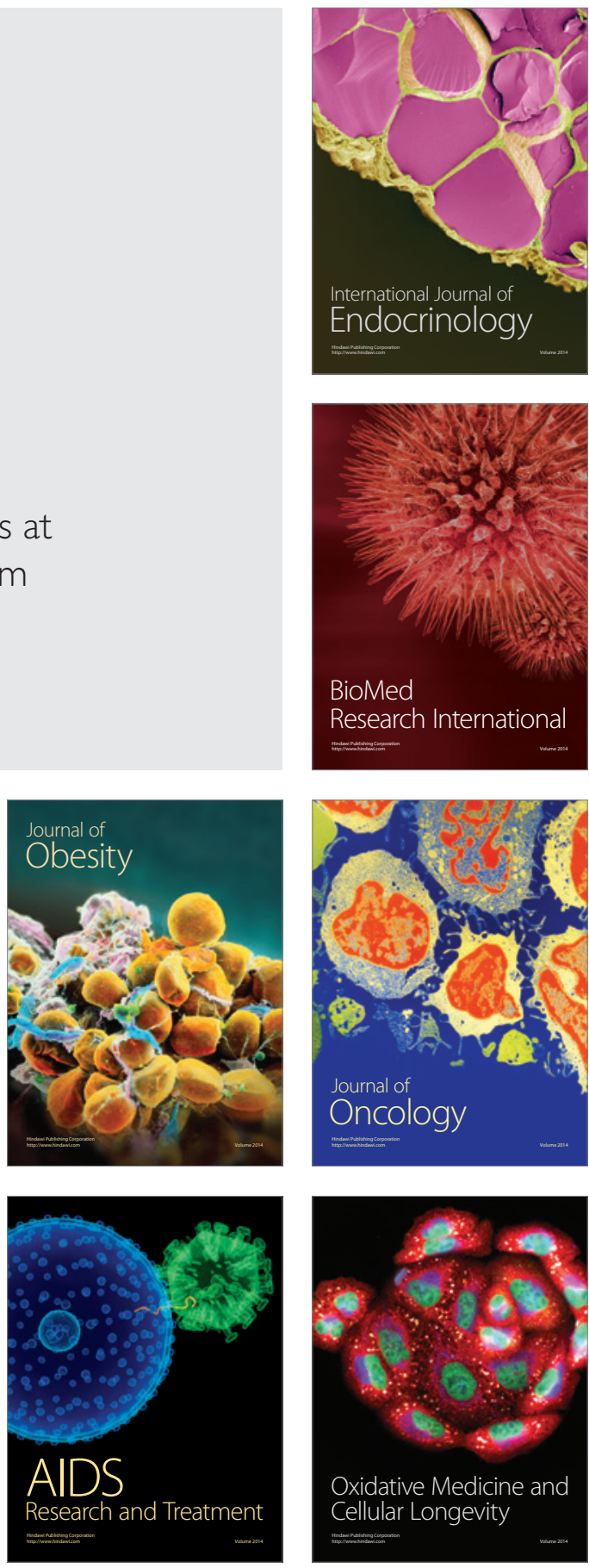